\title{
SMART SPECIALIZATION AS AN INNOVATIVE STRATEGY FOR THE REGIONAL ECONOMIC GROWTH: EXPERIENCE OF CENTRAL AND EASTERN EUROPEAN COUNTRIES FOR UKRAINE
}

\author{
${ }^{\odot 2020}$ VOZNYAK H. V., KLOBA T. L.
}

UDC 332.122:332.021

JEL: 018; 032; 038

\section{Voznyak H. V., Kloba T. L. Smart Specialization as an Innovative Strategy for the Regional Economic Growth: Experience of Central and Eastern European Countries for Ukraine}

The initiated processes of reforming the government and public finances in Ukraine have provided real opportunities for increasing the resources for sustainable development of regional economic systems, communities and territories. At the same time, domestic practice shows ineffective mechanisms for implementing the State, regional policy, deepening both interregional and intra-regional asymmetries in terms of socioeconomic development. These aspects highlight the increased interest in the scientific and practical problem of converting opportunities into tools to stimulate economic growth of territories and updating the State Regional Policy of Ukraine, which should be based on the system of multilevel governance of territories and development of its strategic vision, especially in terms of competitive advantages. The purpose of the study is to systematize the experience of strategizing the regions of the EU, Central and Eastern Europe and to carry out a comparative analysis of the choice of priority areas of smart specialization in terms of groups of regions with appropriate economic structure. The object of the research in this article are the processes of strategizing the regional development on the basis of smart specialization in Ukraine and the EU Member States. In the course of the research a set of general scientific methods of scientific cognition (system analysis, logical generalization, analogy, comparative analysis) was used, which provided an opportunity to realize the integrity of scientific research. The practices of regional strategy on the basis of smart specialization of Central and Eastern European countries are analyzed. Their economic profile and priorities of reasonable specialization are determined. The peculiarities of the functioning of the economy of the countries / regions selected for analysis are highlighted. Emphasis is placed on the consequences / benefits of implementing innovative strategies for the economic progress of countries / regions. A comparative assessment of the priority areas of smart-specialization of the EU and Ukraine in terms of groups of regions with the appropriate structure of the economy is made. As a result of the study, no unambiguous correspondence was established. Recommendations are given and imperatives are determined, upon which the policy of sustainable growth of the Ukraine's regions should be developed, based on the results of the conducted research.

Keywords: region, regional development, strategizing, smart-specialization, strategy, regional policy.

Dol: https://doi.org/10.32983/2222-4459-2020-11-59-68

Fig.: 1. Tabl.: 2. Bibl.: 21.

Voznyak Halyna V. - D. Sc. (Economics), Senior Research Fellow, Leading Researcher of the Department of Regional Financial Policy, Institute of Regional Research named after M. I. Dolishniy of the NAS of Ukraine (4 Kozelnytska Str., Lviv, 79026, Ukraine)

E-mail: gvoznyak@gmail.com

ORCID: $h$ ttp://orcid.org/0000-0003-2001-0516

Researcher ID: http://www.researcherid.com/C-5378-2019

Scopus Author ID: 56912418700

Kloba Taras L. - Postgraduate Student of the Department of Regional Financial Policy, Institute of Regional Research named after M. I. Dolishniy of the NAS of Ukraine (4 Kozelnytska Str., Lviv, 79026, Ukraine)

E-mail: taras.kloba@gmail.com

ORCID: http://orcid.org/0000-0002-3354-3648

Researcher ID: http://www.researcherid.com/R-4504-2018

Scopus Author ID: 57208105217

УДК 332.122:332.021

JEL: 018; 032; 038

Возняк Г. В., Кльоба Т. Л. Смарт-спечіалізація як інновачійна стратегія економічного зростання регіонів: досвід країн Центральної та Східної Європи для України

Розпочаті процеси реформування влади та державних фінансів в Україні обумовили реальні можливості для нарощення ресурсів сталого розвитку регіональних економічних систем, громад і територій. Водночас вітчизняна практика свідчить про неефективні механізми реалізації державної регіональної політики, поглиблення як мінрегіональних, так і внутрішньорегіональних асиметрій за індикаторами соціально-економічного розвитку. Зазначені аспекти актуалізують підвищений інтерес до науково-практичної проблеми конвертування отриманих можливостей в інструменти стимулювання економічного зростання територій та оновлення державної регіональної політики України, яка повинна базуватися на системі багаторівневого врядування розвитком територій і окресленні ії стратегічного бачення, особливо в частині конкурентних переваг розвитку. Метою дослідження є систематизація досвіду стратегування регіонів ЄС, країн Центральної та Східної європи та проведення компаративного аналізу вибору пріоритетних сфер смарт-спеціалізації в розрізі груп регіонів з відповідною структурою економіки. Об'єктом дослідження в даній статті є процеси стратегування регіонального розвитку на засадах смарт-спеціалізації в Україні та країнах - членах ЄС. У процесі дослідження було використано сукупність загальнонаукових методів наукового пізнання (системного аналізу, логічного узагальнення, аналогії, порівняльного аналізу), що забезпечило можливість реалізації цілісності наукового дослідження. Проаналізовано практики стратегування регіонів на засадах смарт-спеціалізації країн Центральної та Східної Європи. Визначено їх економічний профіль та обрані пріоритети смарт-спеціалізації.. Висвітлено особливості функціонування економіки країн/регіонів, обраних для аналізу. Акцентовано на наслідках/перевагах впровадження інноваційних стратегій для економічного поступу країн/регіонів. Проведено порівняльну оцінку пріоритетних сфер смартспеціалізації регіонів ЄC та України в розрізі груп регіонів з відповідною структурою економіки. У результаті дослідження не встановлено однозначної відповідності. Надано рекомендації та визначено імперативи, на яких повинна будуватися політика стійкого зростання регіонів України, спираючись на результати проведених досліджень. 
Ключові слова: регіон, розвиток регіону, стратегування, смарт-спечіалізація, стратегія, регіональна політика.

Рис.: 1. Табл.: 2. Бібл.: 21.

Возняк Галина Василівна - доктор економічних наук, старший науковий співробітник, провідний науковий співробітник відділу регіональної фінансової політики, Інститут регіональних досліджень імені М. І. Долішнього НАН України (вул. Козельницька, 4, Львів, 79026, Україна)

E-mail: gvoznyak@gmail.com

ORCID: http://orcid.org/0000-0003-2001-0516

Researcher ID: http://www.researcherid.com/C-5378-2019

Scopus Author ID: 56912418700

Кльоба Тарас Львович - аспірант відділу регіональної фінансової політики, Інститут регіональних досліджень імені М. І. Долішнього НАН України (вул. Козельницька, 4, Львів, 79026, Україна)

E-mail: taras.kloba@gmail.com

ORCID: $h$ ttp://orcid.org/0000-0002-3354-3648

Researcher ID: http://www.researcherid.com/R-4504-2018

Scopus Author ID: 57208105217

$\mathrm{D}$ ecentralization and reforms in local self-government and territorial structure of power in Ukraine started in 2015 have created new opportunities for the development of communities and regions, provided motivation for local authorities to stimulate the development of their territories, improving the system of intergovernmental fiscal relations. At the same time, it should be acknowledged that there is currently no high degree of correlation between the opportunities provided and the better quality of life of people, regardless of their place of residence. On the contrary, as evidenced by the statistical data and the authors' own observations, we are witnessing the deepening of both interregional and intra-regional asymmetries in the socioeconomic development indicators.

Another layer of problems is related to the implementation of state regional policy. It is meant here that the large-scale reforms have put on a back burner the coordination of authorities at various levels (as well as the public, business in general) as for the implementation of state and regional policy, and the instability of funding for the State Strategy for Regional Development clearly requires normalization. By the way, the norm of the State Fund for Rural Development, which should make up 1\% of the general fund of the state budget, has never been fulfilled in the last five years; amost no funds were allocated to the main oublic treasures within the budget programs (although it is provided by the DSRD); the tasks set by the current strategy faced chronic financial insecurity, etc. The existing state target programs / agreements on regional development are ineffective instruments for the implementation of the DSRD, and implemented projects at the expense of the DFRD are far from being investment development projects aimed at activating the economic potential of territorial development. The annually growing volumes of the subvention for the social and economic development of individual territories which is distributed beyond any established rules have invalidated this mechanism of financial maintenance of regional development.

This proves, on the one hand, the timeliness of the issue of converting the opportunities into tools for stimulating the economic growth of territories and creat- ing conditions for improving the citizens' welfare. On the other hand, it necessitates the renewal of the State Regional Policy of Ukraine, which should be based on current opportunities and challenges, development trends, and problems that constrain it, identifying areas in need of state support, multilevel governance, and thus outlining a strategic vision, which will help Ukraine to achieve the goals. Of course, such a policy will be effective, if it is based on the principles of smart specialization, responds in a timely manner to external and internal challenges, and is stimulating, especially as to the competitive advantages of development.

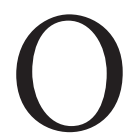
ver the last decade, the issue of substantiating the new paradigm for regional development (the one based on smart specialization as well) has been the subject of discussion within the expert and scientific environment in the European Community, and most recently in Ukraine [1-4]. The fact is that the old methods of implementing regional development policy on a top-down basis have exhausted themselves, as they did not take into account the local characteristics of territories, their strengths/weaknesses as for their economic structure, knowledge institutions, innovation potential and so on. In addition, the interaction between the regions, for the most part, remained out of the attention of governmental officials, who considered them as isolated systems [5]. Based on the above, -we need a new policy of regional development, which would take into account the specialization of the region, be multilevel, innovation-oriented, aimed at strengthening the competitive advantages of the regions, and so on.

It is this policy, which is based on smart specialization of the regions, has recently become especially popular in European countries. The ideologues of the concept (developed in 2008 by a group of experts with the assistance of the European Commission's Directorate for Technology and Innovation) are Dominique Faure, Paul David and Brownsville Hall, who together proposed a concept that had a significant impact on Europe's political audience and hence far beyond it [6]. The key idea of smart specialization was that innovative regions should 
specialize in research and implementation of new general-purpose technologies (digital, nano-, biological, modern materials, etc.), while the weaker regions in terms of innovation were given the mission to promote these technologies. Later, this concept was slightly improved by the developers. According to them, it was inappropriate to link smart specialization only with the strategy of simple industrial specialization in a certain region, as it is a process that solves the problem of lack or weakness of relations between $R \& D$ and innovation resources and activities, on the one hand, and sectoral distribution, on the other. Smart specialization involves abandoning the principle of sharp labor division between producers and consumers of knowledge. Any region faces at least problems of improving the operational efficiency and quality of producing "something", and this is a matter of $R \& D$, opportunities, innovation, and so on [6]. Note that this concept was the answer to the question: why are there significant differences between the economic growth of the United States and Europe? As it turned out, the main reasons for this gap were differences in the labor market (quality of human capital, tough European labor markets, the different organization of investment processes and availability of venture capital), and the key determinant of US economic growth over the past 20 years has been manufacturing and ICT. According to researchers [7]: "... the slowdown in economic growth is due to the slower development of the knowledge economy in Europe than the one in the United States."

$\mathrm{I}$ n 2010, the EU declared its vision for the development of regions in particular and the economy in general in its Europe 2020 Strategy [8], whose priorities were identified as following: smart development based on knowledge and innovation; sustainable development that ensures more efficient resources usage and competitiveness; comprehensive development, which leads to an increase in the level of employment of the economically active population, social and territorial integrity. Part of this strategy was a strategy (national/regional) for research and innovation for smart specialization (RIS 3), which provides an action plan on economic transformation, coordination of financial and entrepreneurial resources to support selected economic activities, defining governance and monitoring mechanisms. In essence, it is a strategic approach to developing a policy of maximizing the innovation potential of the region, identifying and stimulating, unique industries or economic activities, regardless of the economic development of the region. The philosophy of smart specialization is not so much to stimulate innovation as to intensify long-term structural changes in the region's economy and shape policies that will allow the region to occupy its niche in global markets.

Speaking about the development policy of the EU regions on the basis of smart specialization for the period up to 2020, it is important to emphasize the fact that the policy of "cohesion" has played a dominant role in changing the paradigm of EU development towards an integrated, territorial and knowledge-oriented approach to public investment. in the context of multilevel governance. It is interesting to point out that, to achieve the goals of cohesion policy, the EU has allocated 351.8 billion euros for the period 2014-2020 (which is almost 1/3 of the EU budget) [9]. This has provided the EU with an opportunity to update the territorially oriented concept of economic and social development.

In order to work out balanced strategies to developUkraine's regions on the basis of smart specialization and measures to achieve strategic goals, it is advisable to study foreign experience. In the future, we will be interested in the best practices of the regional development strategy in the EU countries, which have proved themselves as positive and served as an impetus for structural changes in the parent regions. To do this, we will conduct a comparative analysis of smart specialization, primarily in the EU, Central and Eastern Europe, as their experience is of practical interest to the regions of transition economies, including Ukraine.

The purpose of the study is to systematize the experience of strategizing the regions of the EU, Central and Eastern Europe and to carry out a comparative analysis of the choice of smart specialization priority areas by groups of regions with appropriate economic structure.

$\mathrm{T}$ The study shows that most EU countries have developed and approved smart specialization strategies (RIS 3) up to 2020 (and some up to 2030), which in accordance with EU regulations [10] represent a national or regional strategy that sets priorities in order to create a competitive advantage by developing and aligning the strong and innovative points of the region or industry with business requirements; market development through cohesion, while avoiding duplication and fragmentation. The smart specialization strategy can be developed separately and can be included in national or regional research and innovation strategies. In addition, it should be noted that the presence of a smart specialization strategy (RIS 3) is a prerequisite for the access to the European investment funds [11]. The European Regional Development Fund (ERDF) promotes sustainable development in various EU regions, the Cohesion Fund (CF) and the European Social Fund (ESF) support employment-related projects across Europe. The key financial mechanism for the implementation of regional policy, the Cohesion Fund, provides assistance to those EU member states whose GDP per capita is less than 90\% of the EU average (usually these are Eastern European countries). In fairness, the EU Council may suspend such assistance to an EU member state in the event of an excessive budget deficit.

A comparative analysis of the smart-specialization of $\mathrm{EU}$ regions by groups of regions having an appropriate structure of the economy (Tbl. 1) has allowed us to make the following generalizations. 
Examples of strategizing the regions of the EU member-states

\begin{tabular}{|c|c|c|}
\hline Country / Region & The structure of the economy & Smart-specialization \\
\hline $\begin{array}{l}\text { Poland } \\
\text { Lesser Poland Voivodeship }\end{array}$ & $\begin{array}{l}\text { Processing industry }-1.97 \% \text {; } \\
\text { wholesale and retail trade }-16.67 \% \text {; } \\
\text { construction }-6.94 \% \text {; } \\
\text { scientific activity }-4.46 \% \text {; } \\
\text { services, including financial, tourist, } \\
\text { communication, information, consult- } \\
\text { ing }->50 \%\end{array}$ & $\begin{array}{l}\text { - Life sciences; } \\
\text { - sustainable energy; } \\
\text { - information and communication technologies; } \\
\text { - chemical industry; } \\
\text { - manufacture of basic metals and fabricated metal } \\
\text { products; } \\
\text { - electrical engineering and mechanical engineering; } \\
\text { - creative industries and leisure }\end{array}$ \\
\hline $\begin{array}{l}\text { Czech Republic } \\
\text { South Moravian Region }\end{array}$ & $\begin{array}{l}\text { Processing industry - } 29.3 \% \text {; } \\
\text { transport and communications - 18\%; } \\
\text { construction }-7.1 \% \text {; } \\
\text { health, public administration, educa- } \\
\text { tion - } 16.4 \% \text {; } \\
\text { real estate transactions }-8.4 \% \text {; } \\
\text { agriculture - } 2.9 \% \text {; } \\
\text { other services (including communica- } \\
\text { tion) - } 17.9 \%\end{array}$ & $\begin{array}{l}\text { - Modern engineering and electrical engineering; } \\
\text { - instrument making (including precision measuring } \\
\text { instruments, sensors); } \\
\text { - IT technologies and software; } \\
\text { - medicine and diagnostics; } \\
\text { - aerospace industry }\end{array}$ \\
\hline Estonia & $\begin{array}{l}\text { Agriculture }-2.8 \% \text {; } \\
\text { services (financial and most ICT) }-68 \% \text {; } \\
\text { industry (mostly processing) }-29.2 \%\end{array}$ & $\begin{array}{l}\text { - Information and communication technologies; } \\
\text { - health care (including medical services); } \\
\text { - mechanical engineering, logistics, chemical industry; } \\
\text { - construction (including "smart homes"); } \\
\text { - wood processing (furniture, windows, doors, de- } \\
\text { sign, cellulose); } \\
\text { - healthy nutrition }\end{array}$ \\
\hline Latvia & $\begin{array}{l}\text { Agriculture }-3.9 \% \text {; } \\
\text { industry - } 22.4 \% \text {; } \\
\text { services, including financial, tourist, } \\
\text { communication, information, consult- } \\
\text { ing }-73.7 \%\end{array}$ & $\begin{array}{l}\text { - Knowledge-based economy; } \\
\text { - information and communication technologies; } \\
\text { - digital transformation (including artificial intelli- } \\
\text { gence, Internet of Things, modeling, visualization); } \\
\text { - biotechnology, biopharmacy, biomedicine; } \\
\text { - modern materials, engineering; } \\
\text { - smart energy }\end{array}$ \\
\hline Romania Northwest region & $\begin{array}{l}\text { Agriculture }-6.24 \% \text {; } \\
\text { construction }-7.62 \% \text {; } \\
\text { industry - } 29.92 \% \text {; } \\
\text { services }-56.22 \%\end{array}$ & $\begin{array}{l}\text { - Agri-food sector; } \\
\text { - health care; } \\
\text { - cosmetology and production of food additives } \\
\text { (production of cosmetics and natural food ingredi- } \\
\text { ents; cosmetic and dietary supplements based on } \\
\text { natural extracts from unique regional resources); } \\
\text { - biotechnology (including innovations in oncology, } \\
\text { modern treatments with new products; innovations in } \\
\text { transplantation, balneology, nutrition, orthopedics); } \\
\text { - production of new materials for "furniture, paper } \\
\text { and packaging" and "plastics and metalworking"; } \\
\text { - advanced production technologies (robotics, } \\
\text { Mechatronics, additive manufacturing (3D printing) } \\
\text { / rapid prototyping; manufacture of machinery and } \\
\text { equipment for the energy sector using renewable } \\
\text { sources); } \\
\text { - ICT (Internet products, cyber security, cloud com- } \\
\text { puting, artificial intelligence, digital currencies, } \\
\text { e-government, e-health) }\end{array}$ \\
\hline
\end{tabular}

Source: made up using https://s3platform.jrc.ec.europa.eu/ [12].

\section{Poland}

The processes of determining the specialization of the Lesser Poland Voivodeship (Poland) started in 2011 (and continue to take place now), and in the initial stages gave impetus to the development of entrepreneurship (both at the expense of the state and European funds), and thus promoted the growth of employment in construction. trade, industry, scientific and technological 
activities (which can be proved by the growing trend of R\&D expenditures). The analysis of statistical data shows the gradual transition of the region's economy from agriculture to the production of plastics, from salt production (Wieliczka) to health tourism; increase in expenditures on information technologies contributed to their introduction in foundry and energy production; convenient transport location and investment attractiveness of the region made it possible to intensify the activities of a number of multinational corporations (Nokia, Shell, Ericson, Motorolla, Luftganza, etc.), which led to the development of related activities, namely financial, consulting, information and other services. It is also interesting that regional specialization by 2020 is more aimed at opening new opportunities due to technological changes in science, which were previously unattainable, and this does not mean a complete "collapse" of the existing economic policy (the region's traditional specialization); it is rather the diversification of specialization areas.

\section{Czech Republic}

The introduction of innovation strategies in the South Moravian Region (Czech Republic) has had a positive effect on its economic progress. For example, if before 2004 the region had the lowest rates of attracting foreign investment in the country (50.6 thousand crowns / person), but since 2005 the successfully selected areas of specialization (engineering, ICT, science) have proven their effectiveness, as it can be seen by the growth value added in selected industries. Mechanical engineering, electrical engineering, and metalworking together account for $20 \%$ of the region's exports. The dynamic development of IT, including that in the traditional specialization, forms a favorable ground for the development of knowledgeintensive enterprises. The region's ability to develop dynamically and compete is provided by companies that carry out their own research and invest in key sectors of the region's economy (engineering, electrical engineering, life sciences, IT); from 2006 to 20011 the number of such companies increased from 263 to 367 (see [13]). Later, these trends formed the basis for RIS (2009-2013), where the key areas of specialization were identified: mechanical engineering (special stands for transport, metal structures), electrical engineering (various measuring instruments, switchboards, substations, electromechanical units), information technology (software for special purposes and for economics, business, IT services outsourcing), the science of life (diagnostics and medical care, e.g. powerful medical facilities in Brno, of Masaryk Institute of Oncology). It is interesting to mention that these areas of specialization are also reflected in RIS 3 of the South Moravian Region for 2014-2020 as well.

\section{Estonia, Latvia}

A good example of the country's development on the basis of smart specialization is Estonia, one of the smallest countries in the EU, which at the same time is one of the countries among the former Soviet republics with the highest GDP/person. The uniqueness of this country lies in the rapid development of the economy, including close cooperation between business and government, significant public investment in science and development, the positive impact (mainly trade relations) of Sweden, Finland, Germany, and a strong information technology sector.

The future vision of the country's development on the basis of smart-specialization is laid down in the approved Innovation Strategy "Knowledge-based Estonia" [14] and the Regional Development Strategy for 2014-2020 [15]. This is the third innovation strategy since 2002, which is based on the results of the previous periods and identifies strategic areas for sustainable growth until 2020, namely: information technology (including cybersecurity and software development); health technologies and services (including biotechnology and e-medicine); efficient use of resources in the areas of materials science, development of a "smart home", healthy nutrition. The uniqueness of this strategy is that 15 districts are grouped into four regions according to their opportunities and unique advantages, and thus, to their potential for growth.

A $\mathrm{n}$ interesting feature of strategizing a small country like Latvia is that, on the one hand, it leaves its economy dependent on several sectors, and on the other hand, it allows us to focus on technological diversification in these sectors and create synergies with other sectors [12]. To prevent the effect of increasing sectoral specialization, Latvia seeks to identify topics for the specialization of knowledge, taking into account the following aspects: the highest potential for creating opportunities for built-in industries of technological diversification of production towards products with higher profitability; clear coordination between education, research, and innovation; the potential to create new industries or new product areas for existing industries as a result of the transfer of knowledge and skills from a research institution and the existing industries. Latvia coordinates its activities with neighboring countries, especially those located in the Baltic region, in order to avoid duplication and fragmentation at the level of the Baltic region.

\section{Romania}

Another example of development that is of practical interest for Ukraine and is based on smart specialization is the North-Western region of Romania (established in 1998 to coordinate regional development at the stage of accession to the EU), which includes 6 counties formed on the basis of conventions / agreements concluded between representatives of the county councils. Similar to Poland (and ultimately to most European regions; and the number of those with approved smart strategies is now 180), this region aims at creating competitive advantages by developing its strengths (research and innova- 
tion among others) in line with business needs. and market opportunities, and it has developed a RIS 3 strategy for 2014-2020 [16].

Sharing the basic principles of EU cohesion policy, as well as recognizing the fact that an individual county does not have enough resources and opportunities to be competitive, Romania decided to join forces in areas where the region has a unique innovation potential and specificity. And this is possible by moving in the following directions: a) structural transformation of the dominant sectors of the economy in order to increase value added and inter-municipal cooperation; b) improving quality and productivity by upgrading sectors through modernization and the introduction of new technologies; c) diversification of sectors in order to implement new activities; d) joint radical business inventions and innovations.

When exploring the features of strategizing the North-West region, an interesting detail catches the researcher's eye: here we see a combination of concepts of smart-specialization and clusters. This combination is of practical interest because, on the one hand, it stimulates entrepreneurial search and innovation, and on the other hand, clusters provide a local concentration of growth opportunities for local actors, deeper cross-sectoral linkages, better scaling of economic effects, etc. In addition, such clusters (and they are created in the field of ICT, furniture production, renewable energy, agri-food, food technology, modern materials and nanotechnology, new materials and tourism) are not limited by state borders (according to RIS 3, cross-border cooperation has been established with the adjacent voivodships in Poland, Hungary, Moldova, Ukraine), which ultimately contributes to the development of new value chains. By the way, the practice of creating clusters is common to all the 8 regions of Romania.

A $s$ for the Ukrainian realities, the vision of regional development of Ukraine for the period up to 2027, presented by the Ministry of Communities and Territories in the main document on strategy, the draft State Strategy for Regional Development until 2027, defines the socioeconomic vector of development and focuses on achieving three goals [17] (Fig. 1).
$\mathrm{T}$ The new model of regional policy, creating the basis of the Strategy, provides for a number of innovations: the concentration of state support in problem areas and at growing-points; directing public investment not only to the creation of "hard" infrastructure but also "soft" development projects based on high-quality diagnostics of potentials and problems in various functional areas; a mandatory condition for the implementation of such state programs/projects is the availability of spatial planning documents (planning schemes for regions, communities, etc.); the policy objects are functional territories that need state support (i.e. funding by the area type). The aim of the renewed regional policy is to improve the living standards of the population regardless of the place of people's residence in a cohesive, decentralized, competitive and democratic Ukraine. Development and unity are human-centered. In this concept, a person becomes an " application point" of the state regional policy.

It should be noted that regional development planning in Ukraine until 2027 is based on the methodology developed under the EU Program "Support for Regional Development Policy in Ukraine" in order to systematize and improve the approach to planning and implementing regional development. In 2018, a group of advisers on the implementation of state and regional policy in Ukraine (the "U-LEAD with Europe" program) supplemented this methodology with an approach that identifies regional priorities on the basis of smart specialization in the strategy process.

Given the fact that since 2015 Ukraine has been implementing the European model of managing regional development, as well as the signed Association Agreement with the EU, which obliges our country to approximate its legislation to EU legislation by the end of 2025, the process of improving strategic regional planning on the basis of smart specialization is inevitable. It is believed that the introduction of smart specialization technology to strategic planning of regional development in Ukraine will identify priority areas in certain sectors of the economy for investment at the regional level, which in turn will improve the use of domestic and borrowed financial resources through developing innovations in potentially promising economic activities.

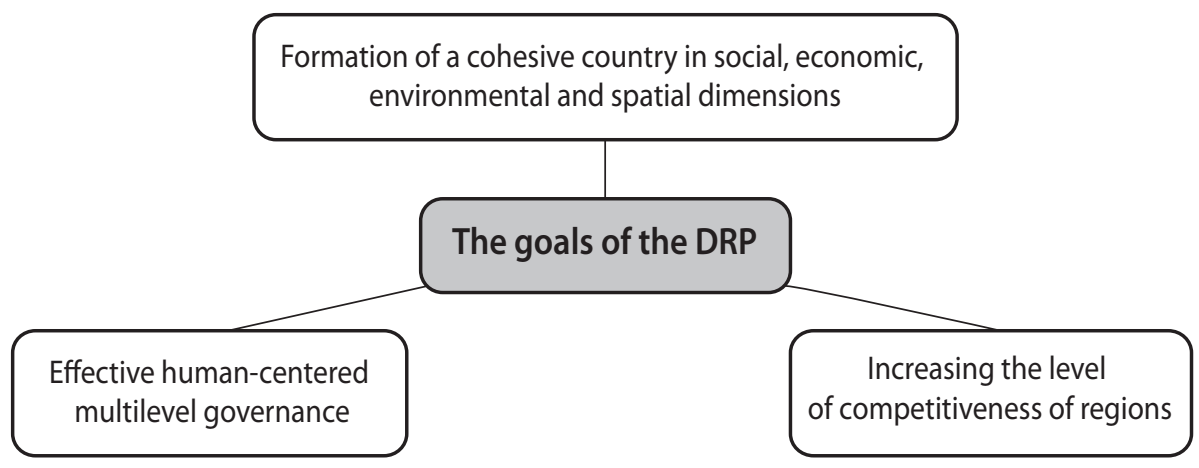

Fig. 1. The goals of the DRP of Ukraine for the period up to 2027 
Given the above, as well as the existing legal framework in Ukraine, regional development strategies (SSR) for the period up to 2027 should be developed on the basis of smart specialization and in accordance with the Order of the Ministry of Regional Development No. 79 dated 31 March 2016 "On approval and evaluation of the effectiveness of the implementation of regional development strategies and action plans for their implementation" [18] and the Resolution of the Cabinet of Ministers of Ukraine No. 932 dated 11 November 2015 "On approval of the Procedure for designing regional development strategies and action plans for their implementation, as well as monitoring and evaluation of the effectiveness of the implementation of these regional strategies and action plans" [19].

S tarting in 2019, Ukraine has begun the process of developing regional strategies for the period up to 2027 , in which at least one of the strategic development goals must be clearly aligned with "smart specialization" (it must provide innovative development of industries or economic activities), which will promote long-term structural changes in the region's economy and increase its level of competitiveness. According to the developed methodology, [20] these development processes should be as public as possible and involve local business, free economic zones, the public, and representatives of local self-government. The criteria for determining the smart specialization of the region, according to the methodology, are the following [21]:

+ resources (assets) availability and the region's capacity (including financial and natural resources, production, science, innovation and human resources);

+ potential ability to diversify economy sectors by developing competitive clusters, intersectoral ties or other economic activities;

+ the presence or projected ability to achieve a high concentration of enterprises in the region, by creating innovative systems of collective effort based on public-private partnerships, among others;

+ the region's place and role in the international and domestic markets.

As of April 2020, 15 regional development strategies have been approved in Ukraine, in which the areas of their specialization have been identified. Their detailed analysis has showed that most regions, while choosing the areas of their specialization, were mainly guided by traditional specialization, sometimes adding 1-2 related areas (Tbl. 2). This is not surprising, because the first smart strategies in Europe were also developed in this way.

A comparative assessment of the priority areas of smart specialization in the EU and Ukraine regions by groups of regions with similar economic structure has not shown a clear correspondence.

\section{CONCLUSIONS}

The conducted research and comparative analysis of European practices of the regional development strategy helps to form conclusions and generalizations that are important in the Ukrainian context, namely:

- Each country goes its own way, there is no universal "recipe" for strategizing at all, just as there are no universal methods for choosing smart specialization (usually a combination of methods is used to get the most complete picture of the existing innovation potential). The strategy of strategizing is unified, but it seems that not all the regions clearly adhere to all the steps of RIS 3 ; still, the vast majority uses the methodological framework of RIS 3 (which is typical for Ukraine).

- All the regions/countries analyzed have developed national/regional research or innovation strategies of smart-specialization, as, on the one hand, it gives guaranteed access to European investment funds and state support (through funding various regional development programs) areas of specialization; on the other, it is an opportunity for the reagions to become leaders / or players in certain fields of knowledge or markets, and therefore to gain advantage in value-added production chains.

- The European practice of prioritizing regional specialization has confirmed the key feature of smart specialization, which is the ability to reasonably link the existing knowledge/innovation with market potential, because knowledge does not always provide an economic effect that will inevitably lead to increased added value in the region. Although, the opposite is obvious, i.e., goods/products/services with a low share of innovation are not competitive. Therefore (and this is clear from the study), the smart-specialization of the region is chosen on the border of several industries / technologies or knowledge (Agri-food sector and biotechnology; engineering and instrument manufacture, etc.), which complement each other.

- There are countries / regions that already have 3-4 innovative smart specialization strategies (for example, the Czech Republic), the results of which (as well as areas of specialization) are a logical continuation of the previous ones. However, it is clear that in the initial stages (after joining the EU) everyone focused on the traditional specialization of the region, and over time (having mastered the funds of various European funds, especially it concerns Polish regions) they: a) partially left the old directions and added 1-2 new ones (related or strategically important for the future); b) created attractive conditions and watched what companies came to the market and created corresponding areas of specialization; c) looked (all of them), where and in which sectors science-innovation-know-how thrive and "pulled them up". A key feature for most regions is that R\&D and innovation spending should increase in the industry; d) it is obvious that "wise" countries (especially those who are interested in technology and engineering) develop related industries, creating production chains with high added value. 
Examples of strategizing individual regions of Ukraine

\begin{tabular}{|c|c|c|}
\hline Region & The economy structure & Smart-specialization \\
\hline Lviv & $\begin{array}{l}\text { Manufacturing - } 23.4 \% \text {; } \\
\text { mining industry }-5.8 \% \text {; } \\
\text { wholesale and retail trade }-12.8 \% \text {; } \\
\text { construction - 5.9\%; } \\
\text { agriculture }-9.5 \% \text {; } \\
\text { research }-4.3 \% \text {; } \\
\text { transport and communication - } 13.5 \% \text {; } \\
\text { real estate transactions - } 4.8 \% \text {; } \\
\text { services - } 20 \%\end{array}$ & $\begin{array}{l}\text { - Processing industry (machinery and instrument } \\
\text { manufacture), textile; } \\
\text { - bioeconomics (woodworking, furniture produc- } \\
\text { tion, printing, food industry, bioenergy); } \\
\text { - creative industries (IT, activities in the field of } \\
\text { creativity and art, production of video products } \\
\text { and advertising materials, provision of information } \\
\text { services); } \\
\text { - MORS (medical tourism, pharmacy, health care }\end{array}$ \\
\hline Kyiv & $\begin{array}{l}\text { Manufacturing - } 33.2 \% \text {; } \\
\text { mining industry }-0.2 \% \text {; } \\
\text { wholesale and retail trade }-13.1 \% \text {; } \\
\text { construction }-8.1 \% \text {; } \\
\text { agriculture }-12.8 \% ; \\
\text { research }-2.2 \% \text {; } \\
\text { transport and communication }-8.7 \% \text {; } \\
\text { real estate transactions }-4.2 \% \text {; } \\
\text { services / other }-17.5 \%\end{array}$ & $\begin{array}{l}\text { - Production of innovative food products with im- } \\
\text { proved consumer qualities (functional food); } \\
\text { - innovative products for construction, design and } \\
\text { everyday life; } \\
\text { - bioactive substances and pharmaceuticals for hu- } \\
\text { man health; } \\
\text { - development of energy efficient solutions based } \\
\text { on alternative energy sources }\end{array}$ \\
\hline Kharkiv & $\begin{array}{l}\text { Manufacturing - } 29.1 \% \text {; } \\
\text { mining industry - } 10.4 \% \text {; } \\
\text { wholesale and retail trade }-9.3 \% \text {; } \\
\text { construction }-5 \% \text {; } \\
\text { agriculture }-10.6 \% \text {; } \\
\text { research - } 3.7 \% \text {; } \\
\text { transport and communication - } 10.8 \% \text {; } \\
\text { real estate transactions - } 4.1 \% \text {; } \\
\text { services / other - } 17 \%\end{array}$ & $\begin{array}{l}\text { - Power engineering; } \\
\text { - production of armored vehicles; } \\
\text { - manufacture in the aviation industry; } \\
\text { - creation and production of new materials; } \\
\text { - biopharmaceuticals; } \\
\text { - information technology; } \\
\text { - creative industry (except information technology); } \\
\text { - agro-processing }\end{array}$ \\
\hline Kherson & $\begin{array}{l}\text { Manufacturing }-24.3 \% \text {; } \\
\text { mining industry }-0.1 \% \text {; } \\
\text { wholesale and retail trade }-9.7 \% \text {; } \\
\text { construction }-2.3 \% \text {; } \\
\text { agriculture }-32.4 \% \text {; } \\
\text { research }-4.6 \% \text {; } \\
\text { transport and communication - } 6 \% \text {; } \\
\text { real estate transactions - } 4.3 \% \text {; } \\
\text { services / other }-16.3 \%\end{array}$ & $\begin{array}{l}\text { - Knowledge-based economy; } \\
\text { - information and communication technologies; } \\
\text { - digital transformation (including artificial intelli- } \\
\text { gence, Internet of Things, modeling, visualization); } \\
\text { - biotechnology, biopharmacy, biomedicine; } \\
\text { - modern materials, engineering; } \\
\text { - smart energy }\end{array}$ \\
\hline
\end{tabular}

Source: made up using [17].

- The following conclusion follows from the study and agrees well with the previous one: in determining the region's specialization, the majority of countries focus either on the region's opportunities / technologies or on innovative products / services / goods for a well-defined market niche (e.g. South Moravian Region,, the NorthWestern part of Romania).

- For Ukraine,it is hardly possible to precisely borrow the experience of the regional development strategy, as we are all different (both economies and opportunities (financial, resource, innovation...), but some aspects of regional development planning on the basis of smartspecialization should be as close to the original ones as posible), and it is now happening, from the methodology and to the justification of specialization area ). It should be noted that most of the approved domestic regional de- velopment strategies until 2027 are written in such a way that smart directions resonate with the traditional specification of the region. And this is not surprising, because as European practice shows, their first smart-strategies were also developed in this style.

\section{LITERATURE}

1. Regional innovation strategies: the challenge for less favoured regions / K. Morgan, C. Nauwelaers (eds.). London : Routledge, 2004. 269 p.

2. Пика Я., Янішевські А. «Smart specializations» у регіональних інноваційних екосистемах. Журнал європейської економіки. 2014. Т. 13. № 1. C. 32-50. URL: http://dspace.wunu.edu.ua/bitstream/ 316497/13133/1/Пика\%20Я..pdf 
3. Healy A. Innovation in Circumpolar Regions: New Chalh lenges for Smart Specialization. The Northern Review. 2017. No. 45. P. 11-32. DOI: https://doi.org/10.22584/nr45.2017.002

4. Amosha O., Liakh O., Soldak M., Cherevatskyi D. (2018), Institutional Determinants of Implementation of the Smart Specialisation Concept: Case for Old Industrial Coal-Mining Regions in Ukraine. Journal of European Economy. 2018. Vol. 17. No. 3. P. 305-332.

DOI: 10.35774/jee2018.03.305

5. Tödtling F., Trippl M. One size fits all?: Towards a differentiated regional innovation policy. Research Policy. 2005. Vol. 34. Issue 8. P. 1203-1219.

DOI: https://doi.org/10.1016/j.respol.2005.01.018

6. Foray D., David P., Hall B. Smart specialization: from academic idea to political instrument, the surprising career of a concept and the difficulties involved in its implementation. MTEI Working Paper. 2011. Lausanne, Switzerland, 16. URL: https://infoscience.epfl.ch/record/170252

7. The Question of R\&D Specialisation: Perspectives and policy implications / D. Pontikakis, D. Kyriakou and R. van Bavel (eds.). Luxembourg, 2009. 100 p. URL: http:// www.eurosfaire.prd.fr/7pc/doc/1253886607_rd_specialisation_jrc51665.pdf

8. EUROPE 2020: A European strategy for smart, sustainable and inclusive growth. Brussels, 2010. URL: https:// ec.europa.eu/eu2020/pdf/COMPLET\%20EN\%20BARROSO\%20\%20\%20007\%20-\%20Europe $\% 202020 \% 20$ $-\% 20$ EN\%20version.pdf

9. Regional Policy / European Commission. URL: https:// ec.europa.eu/knowledge4policy/territorial/topic/regional_en\#Eu2020

10. Regulation (EU) no 1303/2013 of the European Parliament and of the Council. URL: http://eur-lex.europa. eu/legal-content/EN/TXT/?uri=celex\%3A32013R1303

11. Funding / European Commission. URL: https://knowledge4policy.ec.europa.eu/territorial/topic/regional_ en\#Funding

12. Innovation and Research Strategy for Smart Specialization / The Initial Position of Latvia. URL: https:// s3platform.jrc.ec.europa.eu/regions/LV/tags/LV

13. Regionální inovační strategie Jihomoravského kraje 2014-2020. URL: https://www.risjmk.cz/ userfiles/file/Region \%C3\%A 1 In \%C3\%AD\% 20 in ova \% C 4\% 8Dn \% C 3\% AD \% 20strategie $\% 20$ Jihomoravsk\%C3\%A9ho\%20kraje\%202014-2020.pdf

14. Estonian Research and Development and Innovation Strategy 2014-2020 "Knowledge-based Estonia". URL: https://www.hm.ee/sites/default/files/estonian_rdi_ strategy_2014-2020.pdf

15. Eesti regionaalarengu strateegia 2014-2020. URL: https://www.siseministeerium.ee/sites/default/ files/dokumendid/eesti_regionaalarengu_strateegia_2014-2020.pdf

16. Strategia de specializare inteligentă. Regiunea de dezvoltare Nord-Vest (RIS3 NV). URL: https://www. nord-vest.ro/wp-content/uploads/2018/07/RIS3NV-190301.pdf

17. Проект постанови Кабінету Міністрів України «Про затвердження Державної стратегії регіонального розвитку на період до 2027 року». URL: https://www.minregion.gov.ua/base-law/grom- convers/elektronni-konsultatsiyi-z-gromadskistyu/ proekt-postanovi-kabinetu-ministriv-ukrayinipro-zatverdzhennya-derzhavnoyi-strategiyiregionalnogo-rozvitku-na-period-do-2027-roku/

18. Методика розроблення, проведення моніторингу та оцінки результативності реалізації регіональних стратегій розвитку та планів заходів з їх реалізації : затв. Наказом Міністерства регіонального розвитку, будівництва та житлово-комунального господарства України від 31.03.2016 р. № 79. URL: https:// zakon.rada.gov.ua/laws/show/z0632-16\#Text

19. Порядок розроблення регіональних стратегій розвитку і планів заходів з їх реалізації, а також проведення моніторингу та оцінки результативності реалізації зазначених регіональних стратегій і планів заходів : затв. Постановою Кабінету Міністрів України від 11 листопада 2015 р. № 932. URL: https:// zakon.rada.gov.ua/laws/show/932-2015-п\#Text

20. Методологія планування регіонального розвитку в Україні. Інструмент для розробки стратегій регіонального розвитку і планів їх реалізації / Проект $\epsilon_{\text {B- }}$ ропейського Союзу «Підтримка політики регіонального розвитку України». URL: http://green.ucci.org. ua/wp-content/uploads/2016/11/1_METODOLOG_ YA_PLANUVANNYA_REG_ONALNOGO_ROZVYTKU.pdf

21. Наказ Міністерства регіонального розвитку, будівництва та житлово-комунального господарства України «Про внесення змін до наказу Міністерства регіонального розвитку, будівництва та житловокомунального господарства України від 31 березня 2016 року № 79» від 27.12.2018 р. № 373. URL: https:// zakon.rada.gov.ua/laws/show/z0082-19\#Text

\section{REFERENCES}

Amosha, O. et al. "Institutional Determinants of Implementation of the Smart Specialisation Concept: Case for Old Industrial Coal-Mining Regions in Ukraine". Journal of European Economy, vol. 17, no. 3 (2018): 305-332. DOI: 10.35774/jee2018.03.305

"Eesti regionaalarengu strateegia 2014-2020". https://www. siseministeerium.ee/sites/default/files/dokumendid/ eesti_regionaalarengu_strateegia_2014-2020.pdf

"Estonian Research and Development and Innovation Strategy 2014-2020 "Knowledge-based Estonia".". https://www.hm.ee/sites/default/files/estonian_rdi_ strategy_2014-2020.pdf

"EUROPE 2020: A European strategy for smart, sustainable and inclusive growth". Brussels, 2010. https:// ec.europa.eu/eu2020/pdf/COMPLET\%20EN\%20BARROSO $\% 20 \% 20 \% 20007 \% 20-\% 20$ Europe $\% 202020 \% 20$ -\%20EN\%20version.pdf

"Funding". European Commission. https://knowledge4 policy.ec.europa.eu/territorial/topic/regional_ en\#Funding

Foray, D., David, P., and Hall, B. "Smart specialization: from academic idea to political instrument, the surprising career of a concept and the difficulties involved in its implementation". MTEI Working Paper. 2011. Lausanne, Switzerland, 16. https://infoscience.epfl.ch/record/170252 
Healy, A. "Innovation in Circumpolar Regions: New Challenges for Smart Specialization". The Northern Review, no. 45 (2017): 11-32.

DOI: https://doi.org/10.22584/nr45.2017.002

"Innovation and Research Strategy for Smart Specialization". The Initial Position of Latvia. https://s3platform. jrc.ec.europa.eu/regions/LV/tags/LV

[Legal Act of Ukraine] (2015). https://zakon.rada.gov.ua/ laws/show/932-2015-п\#Text

[Legal Act of Ukraine] (2016). https://zakon.rada.gov.ua/ laws/show/z0632-16\#Text

[Legal Act of Ukraine] (2018). https://zakon.rada.gov.ua/ laws/show/z0082-19\#Text

[Legal Act of Ukraine]. https://www.minregion.gov.ua/ base-law/grom-convers/elektronni-konsultatsiyi-zgromadskistyu/proekt-postanovi-kabinetu-ministrivukrayini-pro-zatverdzhennya-derzhavnoyi-strategiyiregionalnogo-rozvitku-na-period-do-2027-roku/

"Metodolohiia planuvannia rehionalnoho rozvytku v Ukraini. Instrument dlia rozrobky stratehii rehionalnoho rozvytku i planiv yikh realizatsii" [Methodology of Regional Development Planning in Ukraine. A Tool for Developing Regional Development Strategies and Plans for Their Implementation]. Proekt Yevropeiskoho Soiuzu «Pidtrymka polityky rehionalnoho rozvytku Ukrainy». http://green.ucci.org.ua/wp-content/uploads/2016/11/1_METODOLOG_YA_PLANUVANNYA REG_ONALNOGO_ROZVYTKU.pdf
Morgan, K. Regional innovation strategies: the challenge for less favoured regions. London: Routledge, 2004.

Pontikakis, D., and Kyriakou, D. "The Question of R\&D Specialisation: Perspectives and policy implications". Luxembourg, 2009. http://www.eurosfaire.prd.fr/7pc/ doc/1253886607_rd_specialisation_jrc51665.pdf

Pyka, Ya., and Yanishevski, A. "«Smart specializations» u rehionalnykh innovatsiinykh ekosystemakh" ["Smart Specializations" in Regional Innovation Ecosystems]. Zhurnal yevropeiskoi ekonomiky. 2014. http://dspace.wunu. edu.ua/bitstream/316497/13133/1/Пика\%20Я..pdf

"Regional Policy". European Commission. https:// ec.europa.eu/knowledge4policy/territorial/topic/regional_en\#Eu2020

"Regionalni inovacni strategie Jihomoravskeho kraje 2014-2020". https://www.risjmk.cz/ userfiles/file/Region\%C3\%A 1 In\%C3\%AD\%20 inova \%C 4\% 8Dn \% C 3\% AD \% 20 strategie $\% 20$ Jihomoravsk\%C3\%A9ho\%20kraje\%202014-2020.pdf

"Regulation (EU) no 1303/2013 of the European Parliament and of the Council". http://eur-lex.europa.eu/ legal-content/EN/TXT/?uri=celex\%3A32013R1303

"Strategia de specializare inteligent?. Regiunea de dezvoltare Nord-Vest (RIS3 NV)". https://www.nord-vest. ro/wp-content/uploads/2018/07/RIS3-NV-190301.pdf

Todtling, F., and Trippl, M. "One size fits all?: Towards a differentiated regional innovation policy". Research Policy, vol. 34, no. 8 (2005): 1203-1219. DOI: https://doi.org/10.1016/j.respol.2005.01.018 